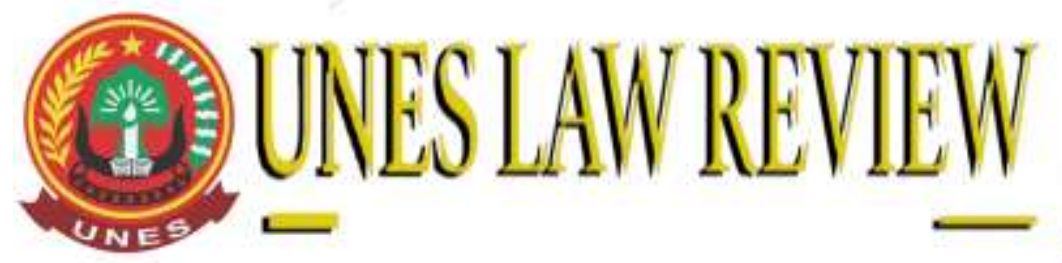

$+6281365118590$ +6281365118590

https://review-unes.com/ uneslawreview@gmail.com

DOI: https://doi.org/10.31933/unesrev.v4i2

Diterima: 01/12/2021, Diperbaiki: 15/12/2021, Diterbitkan: 27/12/2021

\title{
KEABSAHAN PERJANJIAN PINJAM NAMA ANTARA WARGA NEGARA ASING TERHADAP WARGA NEGARA INDONESIA
}

\author{
Oriza Imanda Pratama Ismi Putri ${ }^{1}$, Fatma Ulfatun Najicha ${ }^{2}$ \\ ${ }^{1}$ Fakultas Hukum, Universitas Sebelas Maret, Surakarta, Indonesia. \\ Email: orizaimanda1203@student.uns.ac.id \\ ${ }^{2}$ Fakultas Hukum, Universitas Sebelas Maret, Surakarta, Indonesia. \\ Email: fatmanajicha_law@staff.uns.ac.id
}

Corresponding Author: Oriza

\section{ABSTRACT}

This study aims to analyze the legal provisions in the regulations regarding the nominee agreement and the form of sanctions given to the notary making the nominee agreement deed that is contrary to the UUPA. This type of research is normative juridical and the approach method used is the statutory approach. The results of this study are that the nominee agreement between foreign citizen and Indonesian citizen does not meet the objective requirements for the validity of the agreement, because it does not contain a lawful cause. This is because this agreement was made to do things that are prohibited by law. Foreign nationals do not have ownership rights to land in Indonesia, but only have usufructuary rights to land. This has been regulated in Article 42 of the UUPA. In relation to the notary making the deed of the nominee agreement which is contrary to the UUPA, then administratively, the notary has violated article 16 paragraph (1) letter $d$ of the UUJN, so that it can be subject to sanctions in the form of verbal warning, written warning, temporary dismissal, respectful dismissal, or dishonorable dismissal.

Keywords: Nominee Agreement, Foreign National, Indonesian Citizen, Notary

\section{ABSTRAK}

Penelitian ini bertujuan untuk menganalisis ketentuan hukum dalam peraturan-peraturan mengenai perjanjian pinjam nama dan bentuk sanksi yang diberikan kepada notaris pembuat akta perjanjian pinjam nama yang bertentangan dengan UUPA. Jenis penelitian ini adalah yuridis normatif dan metode pendekatan yang digunakan adalah pendekatan perundang-undangan. Hasil penelitian ini adalah perjanjian pinjam nama antara warga negara asing terhadap warga negara Indonesia tidak memenuhi syarat objektif sahnya perjanjian, karena tidak mengandung sebab yang halal. Hal ini disebabkan karena dibuatnya perjanjian ini adalah guna melakukan hal yang dilarang oleh undang-undang. Warga negara asing tidak memiliki hak milik atas tanah di Indonesia, namun hanya memiliki hak pakai atas tanah. Hal ini telah diatur didalam Pasal 42 
UUPA. Terkait dengan notaris pembuat akta perjanjian pinjam nama yang bertentangan dengan UUPA, maka secara administratif, notaris tersebut telah melanggar Pasal 16 ayat (1) huruf d UUJN, sehingga dapat dikenakan sanksi berupa teguran lisan, teguran tertulis, pemberhentian sementara, pemberhentian dengan hormat, atau pemberhentian dengan tidak hormat.

Kata Kunci: Perjanjian Pinjam Nama, Warga Negara Asing, Warga Negara Indonesia, Notaris

\section{PENDAHULUAN}

Tanah merupakan hal yang sangat penting bagi kehidupan manusia, karena sepanjang hidup hingga akhir hayatnya, manusia akan selalu membutuhkan tanah. Namun ketersedian tanah sangatlah terbatas sedangkan permintaan tanah semakin meningkat karena pertumbuhan penduduk yang semakin bertambah. Tanah merupakan benda tetap yang dijadikan sebagai sarana investasi karena dinilai sangat menguntungkan, hal ini dikarenakan tanah memiliki nilai ekonomis yang selalu mengalami peningkatan setiap tahunnya. Oleh karena itu, harga tanah semakin mahal dikarenakan banyaknya orang yang membutuhkan tanah.

Berbagai Negara berkembang di belahan dunia yang dahulu menerapkan sistem ekonomi tertutup, kini lambat laun memberikan peluang bagi perusahaan-perusahaan yang bergerak dibidang real estate untuk menanamkan investasinya di negara-negara berkembang, sehingga kebutuhan atas tanah semakin bertambah yang digunakan untuk memenuhi kepentingan dari kegiatan usaha para ekspatriat maupun kepentingan pribadinya (Sumanto, 2013).

Perjanjian pinjam nama adalah suatu perikatan antara dua orang yang mana pihak satu ingin meminjam nama dari pihak lainnya agar dapat memiliki suatu benda. Perjanjian pinjam nama pada umumnya dibuat dalam bentuk akta otentik oleh notaris. Salah satu jenis perjanjian pinjam nama yang umum dilakukan adalah perjanjian pinjam nama yang dilakukan antara warga negara asing terhadap warga negara Indonesia guna memiliki tanah dan/atau bangunan di Indonesia dengan status hak milik. Alasan warga negara asing ingin memiliki status hak milik atas tanah dan/bangunan dikarenakan mereka tidak diizinkan oleh undang-undang dan peraturanperaturan yang lainnya, warga negara asing hanya diizinkan memiliki status hak pakai.

Permasalahan dalam penelitian ini adalah: Pertama, bagaimana ketentuan hukum yang ada didalam peraturan-peraturan mengenai perjanjian pinjam nama yang dilakukan oleh warga negara asing terhadap warga negara Indonesia untuk membeli sebidang tanah di Indonesia?; Kedua, bagaimana bentuk sanksi yang diberikan kepada seorang notaris pembuat akta perjanjian pinjam nama yang bertentangan dengan UUPA?

Adapun tujuan penelitian ini adalah untuk mengetahui ketentuan hukum yang ada didalam peraturan-peraturan yang mengatur mengenai perjanjian pinjam nama dan memahami bentuk sanksi yang diberikan kepada notaris pembuat akta perjanjian pinjam nama.

\section{METODE PENELITIAN}

Jenis penelitian yang digunakan dalam penelitian ini adalah yuridis normatif. Artinya hukum dikonsepkan seperti yang tertulis didalam peraturan perundang-undangan (law in books). Penelitian hukum normatif ini didasarkan pada bahan hukum primer dan sekunder, yaitu 
penelitian yang berpedoman terhadap norma-norma yang terdapat didalam peraturan perundangundangan dan jurnal-jurnal yang berkaitan dengan perjanjian pinjam nama atau perjanjian nominee. Metode pendekatan yang digunakan dalam penelitian ini adalah prendekatan perundang-undangan (statute approach). Artinya menelaah regulasi yang berkaitan dengan isu hukum yang sedang dianalisis dalam penelitian ini. Sedangkan teknik analisa bahan hukum yang digunakan adalah teknik pengolahan data secara kualitatif. Dan untuk penyajiannnya dilakukan secara deskriptif analisa yaitu menganalisa data yang disusun secara sistematis.

\section{HASIL DAN PEMBAHASAN}

Ketentuan hukum dalam peraturan-peraturan mengenai perjanjian pinjam nama yang dilakukan oleh warga negara asing terhadap warga negara Indonesia untuk membeli sebidang tanah di Indonesia

Tidak semua orang asing yang memiliki dana dapat memiliki hak atas tanah di Indonesia, hal ini dikarenakan terdapat ketentuan yang membatasi pemilikan tanah dan bangunan bagi orang asing dan badan hukum asing yang diatur didalam Undang-Undang Nomor 5 Tahun 1960 tentang Peraturan Dasar Pokok-Pokok Agraria (UUPA) dan berbagai peraturan pelaksananya (Ardani, 2017).

Kepemilikan tanah di Indonesia tidak terlepas dari hukum yang mengaturnya. Untuk sahnya tindakan kepemilikan tanah oleh warga negara asing, maka diperlukan peraturan perundang-undangan yang bersifat melindungi tindakan kepemilikan tanah. Terhadap warga negara asing dan badan hukum, baik yang didirikan Indonesia maupun yang didirikan luar negeri dengan pengecualian badan-badan hukum tertentu yang diatur dalam Peraturan Pemerintah Nomor 38 Tahun 1963 tentang penunjukan badan-badan hukum yang dapat mempunyai hak milik atas tanah, tidak diberikan hak milik atas tanah di Indonesia (Kartadimadja \& Tenges, 2020). Hal ini sesuai dengan asas yang dianut oleh hukum agraria yaitu asas nasionalitas atau asas kebangsaan yang menyatakan bahwa warga negara asing tidak diizinkan memiliki tanah di Indonesia, Serta, hal ini telah diatur didalam Pasal 21 ayat (1) UU No. 5 Tahun 1960 tentang Peraturan Dasar Pokok-Pokok Agraria yang menyatakan bahwa hanya warga negara Indonesia yang dapat mempunyai hak milik. Namun bagi warga negara asing dalam kegiatannya yang dilaksanakan di Indonesia dan berkaitan dengan pemanfaatan atas tanah Indonesia, warga negara asing ini hanya diberikan hak pakai atas tanah (Aprilla et al., 2018). Dengan syarat, warga negara asing ini sudah berkedudukan di Indonesia. Hal ini telah diatur didalam Pasal 41 dan Pasal 42 UU No. 5 Tahun 1960 tentang Peraturan Dasar Pokok-Pokok Agraria (Damayanti et al., 2015). Bagi warga negara asing yang dapat memiliki hak pakai di Indonesia adalah mereka yang memberikan dampak positif terhadap pembangunan di Indonesia. Bagi warga negara asing yang akan menjadi investor di Indonesia, dapat memiliki tanah di Indonesia melalui perusahaan nasional dalam rangka penanaman modal asing (PMA) yang berdasarkan pada sistem hukum di Indonesia (Rokilah \& Mukaromah, 2018).

Selain Undang-Undang Pokok Agraria yang merupakan peraturan mengenai hak pakai atas tanah yang dapat dimohonkan oleh warga negara asing, Pemerintah juga mengeluarkan Peraturan 
Pemerintah Nomor 40 Tahun 1996 tentang Hak Guna Bangunan, Hak Guna Usaha dan Hak Pakai atas Tanah. Peraturan Pemerintah ini masih berlaku hingga sekarang. Didalam Peraturan Pemerintah No. 40 Tahun 1996 menjelaskan mengenai batasan jangka waktu hak pakai atas tanah yaitu selama 25 (dua puluh lima) tahun sejak sertifikat hak pakai atas tanah dikeluarkan. Jika warga negara asing melanggar jangka waktu yang telah ditentukan tersebut dan ingin memiliki tanah tersebut selama-lamanya, hal ini disebut suatu tindakan penyulundupan hukum (Aprilla et al., 2018). Hal ini biasanya dipermudah oleh notaris yang membuat perjanjian Trustee. Perjanjian Trustee yaitu bank melakukan kegiatan Trust yang sesuai dengan ketentuan didalam Peraturan Bank Indonesia (PBI) antara warga negara asing dengan warga negara Indonesia untuk melakukan tindakan melawan hukum. Dalam hal ini, warga negara asing sebagai trustor dan penerima manfaatnya dan seorang warga negara Indonesia sebagai trustee yang dipercaya untuk digunakan atau dipinjam namanya (perjanjian nominee). Meskipun masalah ini sering terungkap di publik, namun permasalahan terhadap kepemilikan hak atas tanah yang dilakukan secara bersama-sama oleh warga negara asing, warga negara Indonesia, dan notaris, pada kenyataaanya sangat sulit dibuktikan dan belum dapat dituntaskan (Kartadimadja \& Tenges, 2020).

Jangka waktu hak pakai atas tanah yang telah diatur didalam hukum agraria, hal ini dirasa oleh banyak warga negara asing masih belum cukup untuk menyelesaikan segala kegiatannya yang berkaitan dengan tanah di Indonesia. Oleh karena itu, kemudian terjadilah tindakantindakan yang dilakukan untuk melegalkan lamanya jangka waktu terhadap hak pakai atas tanah yang sedang dikuasainya yaitu melalui serangkaian perjanjian yang melibatkan warga negara Indonesia, khususnya warga lokal yang berada di daerah tersebut. Tindakan untuk melegalkan yang dimaksud adalah dengan dibuatnya perjanjian perjanjian yang bertujuan untuk mendapatkan jangka waktu lebih lama dari yang telah ditentukan, yakni jual beli tanah dengan mekanisme pinjam nama terhadap warga negara Indonesia yang dilakukan oleh warga negara asing. Mekanisme dari perjanjian ini adalah warga negara asing membeli sebidang tanah dan kemudian diatasnamakan warga negara Indonesia pada sertifikat hak milik atas tanah. Hal ini dilakukan dengan tujuan agar warga negara asing ini memiliki hak secara penuh atas tanah yang telah ia beli. Oleh karena itu, secara de jure, objek perjanjian berupa sebidang tanah tersebut telah menjadi hak milik dari warga negara Indonesia. Namun, secara de facto, hal ini berlaku sebaliknya yaitu objek perjanjian berupa sebidang tanah tersebut menjadi hak milik warga negara asing tersebut.

Berdasarkan ketentuan Pasal 26 ayat (2) Undang-Undang Pokok Agraria yang menyatakan bahwa "Setiap jual beli, penukaran, penghibahan, pemberian dengan wasiat dan perbuatanperbuatan lain yang dimaksudkan untuk langsung atau tidak langsung memindahkan hak milik kepada orang asing, kepada seorang warganegara yang disamping kewarganegaraan Indonesianya mempunyai kewarganegaraan asing atau kepada suatu badan hukum, kecuali yang ditetapkan oleh Pemerintah termaksud dalam pasal 21 ayat (2), adalah batal karena hukum dan tanahnya jatuh kepada Negara, ...”. Jatuhnya tanah objek sengketa tersebut ke pihak negara, hal ini menjadikan sertifikat hak milik atas nama warga negara Indonesia batal demi hukum dan 
selanjutnya tanah tersebut dapat dimohonkan hak kepemilikannya oleh orang lain selain warga negara Indonesia (Aprilla et al., 2018). Selain peraturan-peraturan tersebut, perjanjian nominee juga dilarang didalam ketentuan Pasal 1320 Kitab Undang-Undang Hukum Perdata (KUHPerdata) yang menyatakan empat syarat sahnya perjanjian yaitu kesepakatan, kecakapan, objek tertentu, dan sebab yang halal. Perjanjian pinjam nama tidak memenuhi syarat 'sebab yang halal'. Hal ini disebabkan karena dibuatnya perjanjian ini adalah guna melakukan hal yang dilarang oleh undang-undang.

Bentuk sanksi yang diberikan kepada seorang notaris pembuat akta perjanjian pinjam nama yang bertentangan dengan Undang-Undang Pokok Agraria

Perjanjian nominee atau perjanjian pinjam nama merupakan bentuk kepemilikan hak atas tanah oleh warga negara asing yang dilakukan melalui pembuatan perjanjian dibawah tangan dan dalam bentuk akta notaris. Perjanjian pinjam nama yang dibuat di bawah tangan dilakukan oleh para pihak dengan cara menandatangani sendiri perjanjiannya, tanpa adanya perantara dari notaris, namun kemudian perjanjian tersebut dilegalisasi oleh notaris. Perjanjian pinjam nama yang dilegalisasi ini merupakan perjanjian yang disahkan oleh notaris dan ditetapkan kepastian tanggal penandatangan perjanjiannya dengan cara mendaftarkannya ke dalam buku khusus (Novia Ermida, 2018). Salah satu syarat yang harus dipenuhi agar keotentikan suatu perjanjian pinjam nama dapat terpenuhi yaitu perjanjian tersebut harus dibuat di hadapan notaris. Hal ini telah diatur didalam Pasal 15 ayat (1) Undang-Undang Jabatan Notaris. Kewenangan notaris dalam membuat akta otentik merupakan suatu perbuatan hukum yang dapat dipertanggungjawabkan secara hukum dan tidak memihak kepada para pihak manapun (Komang et al., 2020).

Menurut Undang-Undang Jabatan Notaris, seorang notaris dalam melaksanakan jabatannya dapat dipertanggungjawabkan secara administratif dan perdata. Berkaitan dengan akta yang dibuat oleh notaris merupakan akta yang bersifat otentik, maka notaris dalam membuat akta harus selalu berpedoman pada peraturan-peraturan yang berlaku. Apabila notaris membuat akta perjanjian pinjam nama yang bertentangan dengan Undang-Undang Pokok Agraria, maka secara administratif notaris tersebut telah melanggar ketentuan Pasal 16 ayat (1) huruf d UndangUndang Jabatan Notaris, sehingga dapat dikenakan sanksi berupa:

1. Teguran lisan;

2. Teguran tertulis;

3. Pemberhentian sementara;

4. Pemberhentian dengan hormat; atau

5. Pemberhentian dengan tidak hormat.

Sanksi administratif bersifat reparatoir, artinya adalah pengenaan sanksi administratif harus dilakukan secara berjenjang, yaitu dimulai dari sanksi yang terendah berupa teguran lisan hingga sanksi yang terberat berupa pemberhentian dengan tidak hormat. Institusi yang berwenang menjatuhkan sanksi administratif kepada notaris adalah Majelis Pengawas Wilayah (MPW) dan Majelis Pengawas Pusat (MPP). Kewenangan tersebut didasarkan pada : 
1. Pasal 73 ayat (1) huruf e Undang-Undang Jabatan Notaris yang menentukan bahwa Majelis Pengawas Wilayah berwenang untuk memberikan teguran lisan atau tertulis.

2. Pasal 77 huruf c Undang-Undang Jabatan Notaris yang menentukan bahwa MPP berwenang untuk menjatuhkan sanksi pemberhentian sementara kepada notaris.

Sanksi perdata bagi notaris telah diatur didalam Pasal 84 Undang-Undang Jabatan Notaris. Didalam Pasal ini dinyatakan bahwa notaris dapat dituntut berupa penggantian biaya, ganti kerugian, dan bunga. Hal ini berlaku apabila pihak korban mengalami kerugian akibat perbuatan notaris yang melakukan pelanggaran terhadap Pasal 16 ayat (1) huruf i, Pasal 16 ayat (1) huruf k, Pasal 41, Pasal 44, Pasal 48, Pasal 49, Pasal 50, Pasal 51, atau Pasal 52 Undang-Undang Jabatan Notaris.

Pelanggaran terhadap pasal-pasal yang disebutkan dalam Pasal 84 Undang-Undang Jabatan Notaris tersebut, termasuk tindakan pelanggaran terhadap syarat-syarat formil pembuatan akta otentik yang mengakibatkan akta tersebut batal demi hukum (Novia Ermida, 2018). Apabila dikaitkan dengan pembuatan akta perjanjian pinjam nama yang isinya bertentangan dengan Undang-Undang Pokok Agraria, maka tidak dapat dikenakan sanksi perdata, meskipun antara akta perjanjian pinjam nama dan akta sebagaimana akibat perbuatan notaris yang disebutkan dalam Pasal 84 UUJN adalah sama-sama merupakan akta yang batal demi hukum. Hal ini dikarenakan, jika pada akta perjanjian pinjam nama, isinya bertentangan dengan Undang-Undang Pokok Agraria, sedangkan akta yang merupakan akibat dari perbuatan notaris dalam Pasal 84 Undang-Undang Jabatan Notaris, disebabkan karena adanya tindakan pelanggaran terhadap syarat-syarat formil pada pembuatan akta otentik. Sehingga dapat disimpulkan bahwa, UndangUndang Jabatan Notaris tidak mengatur sanksi perdata bagi notaris yang membuat akta perjanjian pinjam nama yang isinya bertentangan dengan Undang-Undang Pokok Agraria.

\section{KESIMPULAN}

Berdasarkan Peraturan Pemerintah Nomor 38 Tahun 1963, warga negara asing tidak diberikan hak milik atas tanah di Indonesia. Hal ini juga telah diatur didalam Pasal 21 ayat (1) UUPA yang menyatakan bahwa hanya warga negara Indonesia yang dapat mempunyai hak milik. Warga negara asing hanya diberikan hak pakai atas tanah, dengan syarat, warga negara asing tersebut sudah berkedudukan di Indonesia. Hal ini telah diatur didalam Pasal 41 dan Pasal 42 UUPA.

Berdasarkan Peraturan Pemerintah Nomor 40 Tahun 1996 yang menjelaskan bahwa batasan jangka waktu hak pakai atas tanah yaitu selama 25 (dua puluh lima) tahun sejak sertifikat hak pakai atas tanah dikeluarkan. Hal ini dirasa oleh warga negara asing masih belum cukup untuk menyelesaikan segala kegiatannya di Indonesia. Oleh karena itu, kemudian warga negara asing melakukan tindakan untuk melegalkan lamanya jangka waktu terhadap hak pakai atas tanah tersebut dengan cara dibuatnya perjanjian pinjam nama terhadap warga negara Indonesia untuk membeli sebidang tanah, dengan tujuan agar warga negara asing tersebut memiliki hak penuh atas tanah yang telah ia beli. 
Berdasarkan Pasal 26 ayat (2) UUPA yang intinya menjelaskan bahwa segala perbuatan yang bertujuan untuk memindahkan hak milik kepada orang asing, kecuali yang ditetapkan oleh Pemerintah termaksud dalam pasal 21 ayat (2), adalah batal karena hukum dan tanahnya jatuh kepada Negara. Jatuhnya tanah objek sengketa tersebut ke pihak negara, hal ini menjadikan sertifikat hak milik atas nama warga negara Indonesia batal demi hukum. Perjanjian pinjam anma juga dilarang didalam Pasal 1320 KUHPerdata karena perjanjian pinjam nama tidak memenuhi syarat sahnya perjanjian yaitu sebab yang halal. Hal ini disebabkan karena dibuatnya perjanjian ini adalah guna melakukan hal yang dilarang oleh undang-undang.

Terkait dengan bentuk sanksi yang diberikan kepada notaris pembuat akta perjanjian pinjam nama yang bertentangan dengan UUPA, maka secara administratif notaris tersebut telah melanggar ketentuan Pasal 16 ayat (1) huruf d Undang-Undang Jabatan Notaris, sehingga dapat dikenakan sanksi berupa teguran lisan, teguran tertulis, pemberhentian sementara, pemberhentian dengan hormat, atau pemberhentian dengan tidak hormat. Pihak yang berwenang menjatuhkan sanksi administratif kepada notaris adalah Majelis Pengawas Wilayah (MPW) dan Majelis Pengawas Pusat (MPP).

\section{DAFTAR PUSTAKA}

Aprilla, A. P., Permadi, I., \& Effendi, L. (2018). Status Hukum Hak Milik Atas Tanah Warga Negara Asing Dengan Meminjam Nama Warga Negara Indonesia. Jurnal Ilmiah Pendidikan Pancasila Dan Kewarganegaraan, 3(1), 15-21.

Ardani, M. N. (2017). Kepemilikan Hak Atas Tanah Bagi Orang Asing Di Indonesia. Jurnal Law Reform Program Studi Magister Ilmu Hukum, 13(2), 204-216.

Damayanti, A. (2015). Perjanjian Nominee Dalam Kepemilikan Tanah Bagi Warga Negara Asing Yang Berkedudukan Di Indonesia (Studi Putusan Pengadilan Tinggi Nomor: 12/PDT/2014/PT.DPS). Jurnal Repertorium, 2(2), 96-104.

Kartadimadja, T. S., \& Tenges, J. E. (2020). Analisis Keabsahan Kepemilikan Tanah Oleh Orang asing Di Indonesia. PALAR (Pakuan Law Review), 6(1), 28-52.

Komang, I., Suwanjaya, G., Sumardika, N., Made, N., \& Ujianti, P. (2020). Perjanjian Pinjam Nama Sebagai Bentuk Kepemilikan Tanah Oleh Warga Negara Asing di Bali. Jurnal Konstruksi Hukum, 1(2). 384-387.

Rokilah, \& Mukaromah, M. (2018). Pemilikan Hak Atas Tanah bagi Warga Negara Asing. AJUDIKASI : Jurnal Ilmu Hukum, 2(2), 137-150.

Sumanto, L. (2013). Pembatasan Pemilikan Hak Atas Tanah Oleh Orang Asing Dan Badan Hukum Asing (Studi Perbandingan Indonesia-Turki). Jurnal Hukum PRIORIS, 3(3), 67102.

Winarta, E. N. (2017). Hak Pakai Atas Rumah Hunian Warga Negara Asing Dalam Perkawinana Campuran Tanpa Perjanjian Kawin. Jurnal Ilmiah Prodi Magister Kenotariatan, 42-57.

Novia Ermida, P. (2018). Analisis Yuridis Terhadap Perjanjian Pinjam Nama Sebagai Bentuk Kepemilikan Tanah Oleh Warga Negara Asing. (Universitas Sumatra Utara, 2018). Diakses dari https://repositori.usu.ac.id/handle/123456789/4963 
Undang-Undang Nomor 5 Tahun 1960 tentang Peraturan Dasar Pokok-Pokok Agraria (UUPA)

Kitab Undang-Undang Hukum Perdata (KUHPerdata)

Undang-Undang Jabatan Notaris

Peraturan Pemerintah Nomor 38 Tahun 1963 Tentang Penunjukan Badan-Badan Hukum yang Dapat Mempunyai Hak Milik Atas Tanah

Peraturan Pemerintah Nomor 40 Tahun 1996 Tentang Hak Guna Usaha, Hak Guna Bangunan Dan Hak Pakai Atas Tanah 